NASA Technical Memorandum 105777

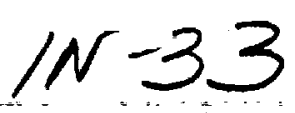

$1 / 4 / 27$

p $q$

Wiring for Aerospace Applications

J.L. Christian, Jr., J.E. Dickman, R.W. Bercaw,

and I.T. Myers

National Aeronautics and Space Administration

Lewis Research Center

Cleveland, Ohio

- A.N. Hammoud and M. Stavnes

Sverdrup Technology, Inc.

Lewis Research Center Group

Brook Park, Ohio

and

J. Evans

Code $Q E$

NASA Headquarters

Washington, $D C$

Prepared for the

1992 Power Electronics Specialist Conference

sponsored by the Institute of Electrical and Electronics Engineers

Toledo, Spain, June 29-July 3, 1992

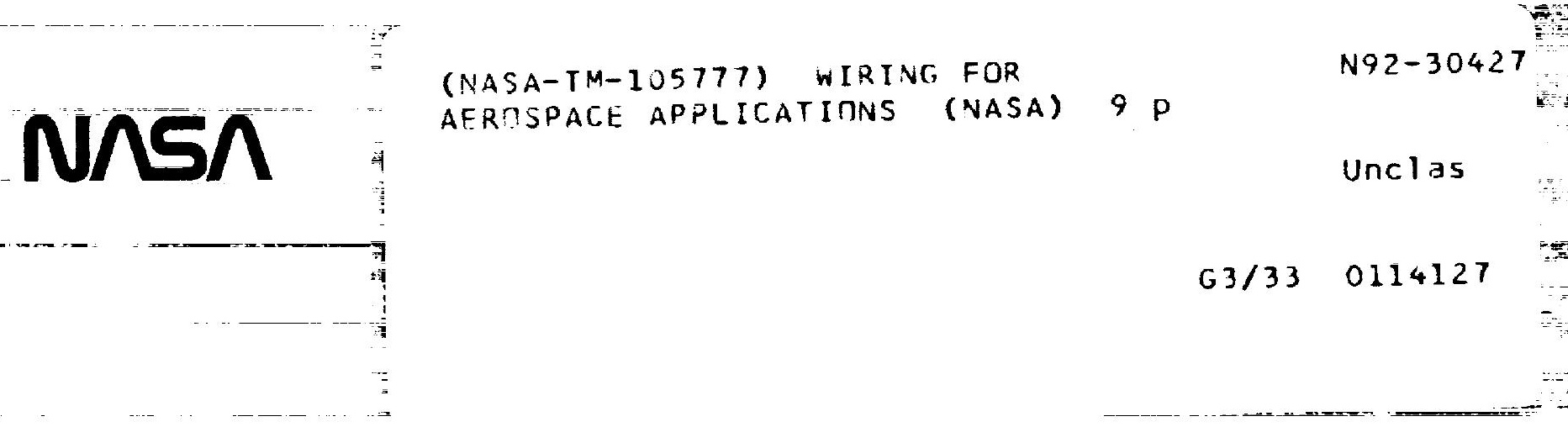




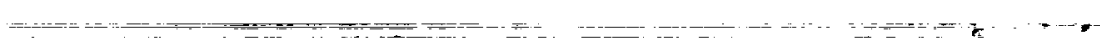




\section{WIRING FOR AEROSPACE APPLICATIONS}

\author{
J.L. Christian, Jr., J.E. Dickman \\ R.W. Bercaw, \& I.T. Myers \\ NASA Lewis Research Center \\ MS 301-2 \\ 21000 Brookpark Rd. \\ Cleveland, Ohio 44135 \\ U.S.A.
}

\author{
A. N. Hammoud \& M. Stavnes \\ Sverdrup Technology, Inc. \\ Lewis Research Center Group \\ 21000 Brookpark Rd. \\ Cleveland, Ohio 44135 \\ U.S.A.
}

\author{
J. Evans \\ Code OE \\ NASA Headquarters \\ Washington, DC 20546 \\ U.S.A.
}

\begin{abstract}
In this paper the authors summarize the current state of knowledge of arc propagation in aerospace power wiring and efforts by the National Aeronautics and Space Administration (NASA) towards the understanding of the arc tracking phenomena in space environment. Recommendations will be made for additional testing. A database of the performance of commonly used insulating materials will be developed to support the design of advanced high power missions, such as Space Station Freedom and Lunar/Mars Exploration.
\end{abstract}

\section{INTRODUCTION}

Failures in aerospace vehicles have been reported both on the ground and inflight due to persistent arcs in the wiring harnesses. The arc typically propagates along the wire and causes the loss of the entire wire harness along with all associated functions. Such lailure mechanisms, which are not accounted lor in the present engineering design practices, represent a serious problem for advanced aerospace vehicles. In this paper, a summary will be given of the current understanding in the area of arc propagation in commonly used wiring insulation malerials. The polential hazards associated with arc propagation and state-of-the-art development of new arc resistant materials for aerospace applications will be presented. A description will be given of the NASA program to assure the salely and reliability of space wiring systems.

\section{ARC PROPAGATION}

In aerospace applications, the eflects of insulation failure can be very costly in terms of loss of expensive equipment, imperilment of missions, and loss of lives. Since the mid sixties, MIL-W-81381 (polyimide insulaled wire) has been the material of choice lor most aerospace applications due 10 its high dielectric strength, excellent thermal properties, non flammability, low weight, and high abrasion resistance. However, insulation tailures became unexpectedly common in a number of applications. This prompted some US Federal Agencies to launch studies to characterize the problem and to search for subslitutes for polyimide ${ }^{1}$ insulation. It resulted in the United States Navy banning the use of polyimide as a wiring insulator in their ships and planes.

The studies found that there are two steps in the failure process. Damage, cracking, or deterioration of the insulation can occur due to exposure to water or certain other liquids, or when the material is subject to mechanical stresses (such as sharp bending). These conditions provide a path from the live wire to ground through which an arc may be initiated. The extreme heat from the electrical arc causes pyrolysis of the polyimide film and forms a conductive path

1. Polyimide insulation is frequenty referred to as Kapton, which is a popular brand manufactured by Dupont. of carbon residue that is referred to as a carbon arc track. This carbon arc track frequently has a sufficiently high electrical resistance to limit the currents to values that do nol trip the circuit breaker. When this is the case, nothing prevents the arc from propagating along the entire wire. Even if the circuit breaker is tripped, reselting it will restart the arc and cause further damage lo the harness. Arc tracking can result in flashover in which the arc jumps to adjacent wires within the same bundle and damages them as well. The rate and extent of arc propagation depends on the lollowing: (a) type of insulation material, (b) applied vollage (magnitude and frequency), (c) wire gauge, and (d) environmental lactors (moisture, temperafure, proximity, elc...).

\section{NASA'S INVOLVEMENT}

NASA will engage in manned and unmanned space missions that will demand greater amounts of electrical power than loday's spacecraft, increasing the likelihood of arc-induced failures. Some of the systems 10 be developed are Space Station Freedom ( $75 \mathrm{kWe}$ ), Mars Cargo and Piloted Vehicles (2 MWe - $10 \mathrm{MWe}$ ), and the First Lunar Outpost ( $12 \mathrm{kWe}$ ).

Because little is known about the phenomenon of arc tracking in space, NASA held a workshop ${ }^{2}$ to assess issues and concerns on electrical wiring for space applications. The attendees included representatives of several US Federal Agencies, National Laboralories, academia, and private industry having particular expertise in the field. The workshop covered: operational experience with polyimide insulation, results of several test programs, wiring requirements for a variety of space missions, and properties of alternate materials.

Operational difficulties were reported with: 1) the Space Transportation System (STS), in which six incidents were reported; 2) numerous arcing incidents and fires in U.S. military aircraft; and 3) a variely of isolated incidents, such as an expensive electrical fire in the $\mathrm{Ma}$ gellan spacecraft ground support equipment.

Two of the most comprehensive studies were: the Wright Re search Developmenl Center / McDonnell Aircraft Company evaluations on new insulation constructions for aeronautical applications, and the NASA's White Sands Test Facility in White Sands, New Mexico, on power requirements for arc propagation under STS conditions. Some important test results reported at the workshop include: 1) arc propagation in polyimide-insulated wires was demonstrated at very low power levels (4 - 8 Watts) [1]; 2) arc tracking and propagation in polyimide was found to occur in the Space Station Freedom (SSF) solar array flexible current carriers[2]; and 3) at voltages as low as $270 \mathrm{Vdc}$, all types of insulation tested to dale exhibited arc propagation[3].

2. Workshop on Wiring for Aerospace Applications", held al NASA Lewis Research Center, Cleveland, Ohio, on the 23-24 of July, 1991 
A number of papers discussed the complexities of the space environments and how insulation may be affected by enviromental factors such as: vacuum, radialion, wide temperature swings, space plasma, zero gravity, and atomic oxygen. Finally, there were discussions of a number of alternate materials and wire / insulation constructions. While there was a number of attractive candidales, it was emphasized by several speakers that wiring must be considered as a system in which careful tradeofts must be made between various properties and requirements.

A major conclusion of the workshop was that the testing to date was inadequate to determine the performance of insulation in the complex environment of space; the tests were not conclusive be cause they only addressed the limited range of operational conditions lor aircrafts and STS. Therefore, it was concluded that there is a need lor the establishment of a broader test matrix and for additional experimental work which emphasize those lest parameters that reflect the enviromental stresses expected to be encounlered in current and fulure NASA space missions.

\section{PROGRAM OVERVIEW}

The NASA's Office of Salety and Mission Quality has initiated a three year eflort at the Lewis Research Center to address some of these issues. The goal of this program is to provide the information and guidance needed to develop and qualify lightweight, sale and reliable wiring systems that are both resistant to arc tracking and suitable in all ways for use in space applications. The eventual goal of this program is the construction of a database containing the performances of commonly used insulating materials that could be utilized in the design of advanced missions, such as SSF and Lunar/ Mars exploration.

To accomplish this mission, this program was divided into three major tasks: 1) define space wiring application requirements; 2) define and pertorm the additional testing and analysis needed to assess available malerials and constructions; and 3) review issues in the design of complele wiring systems. The next three sections provide an interim report on the results of these tasks.

\section{Soace Missions Environments}

The objective of this task is to identify typical requirements and environments (as relevant to electrical power wiring) for NASA space missions and systems, and to evaluate the adequacy of the findings of previous lest programs in assessing wiring systems for NASA missions. A survey of NASA missions was made to identily environmental characteristics that would impose particular requirements on insulation for electrical wiring systems. From the results, five typical environments were identified as being characteristic of those in present and future NASA missions with respect to their operational requirements for the wiring systems. These environments are characteristic of: 1) pressurized modules (characteristic of SSF, and other manned missions), 2) LEO/GEO 3 applications, 3) trans-atmospheric vehicles, 4) Lunar surface, and 5) Mars surface. A brief description of each of these environments follows.

Pressurized module; Since the purpose of a pressurized module, such as those lound in the STS orbiter and the Space Station Freedom, is to protect the crew, the wiring experiences a comparatively narrow temperalure range and benign environment. [4].

Inside the pressurized modules, the potential exists for high humidity because of the presence of humans, however, the actual level of humidity is expected to be regulated. For the pressurized modules

3. LEO $=$ Low Eanth Obit, about $300 \mathrm{~km}$ of athude, and GEO $=$ Geo stationary Orbit, which is about $32,000 \mathrm{~km}$ equatorial orbit.
Figure 1. Vibration Environment of Payloads for Launch Systems [8]

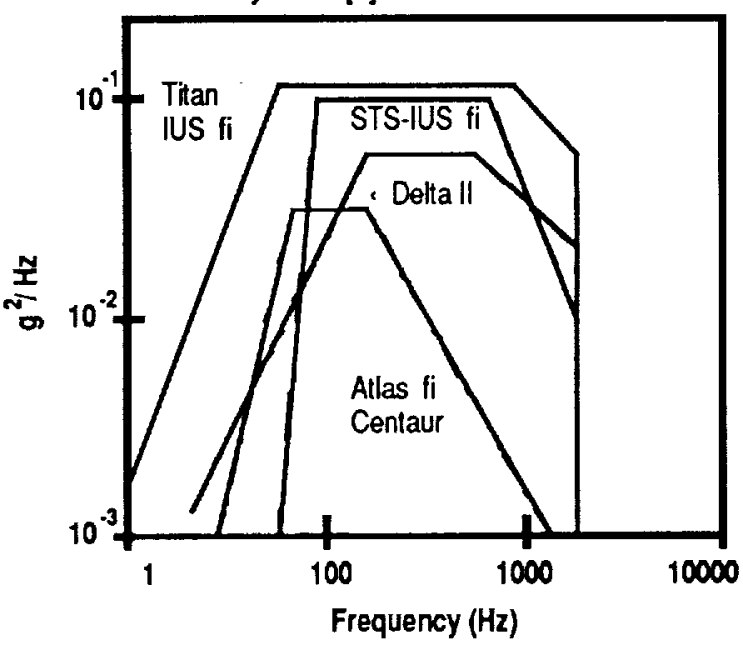

a $30 \%$ oxygen environment increases the danger in the case of a fire. The lires on board the Apollo 1 and 13 were fueled by high oxygen concentration environments (Apollo 1 was $100 \%$ oxygen) $[5,6]$. However, the moisture environment itself is insulficient to cause cracking and is reversed when power is applied $[4,7]$.

Because of the vibration during the launch phase, all wires and cables must be restrained from movernent. The vibration to which the pressurized module wiring is exposed is intense but short-lived (roughly 2 minutes of vibration during launch) $[4,7]$. This is clearly described in figures 1 and 2, and in table 1 . The enclosed manned environment requires that if outgassing were to occur, no significant amounts of toxic compounds may be released.

The function of the pressurized modules is for the habitation of the astronauts and for laboratory experiments. These types of operations may increase the possibility of fluids coming in conlact with wiring insulation. In the case of the pressurized modules for Space Station Freedom, there will be voltages as high as 120 V DC inside of the modules.

Figure 2. Acoustic Environment of Payloads for Launch System SPL (dB)

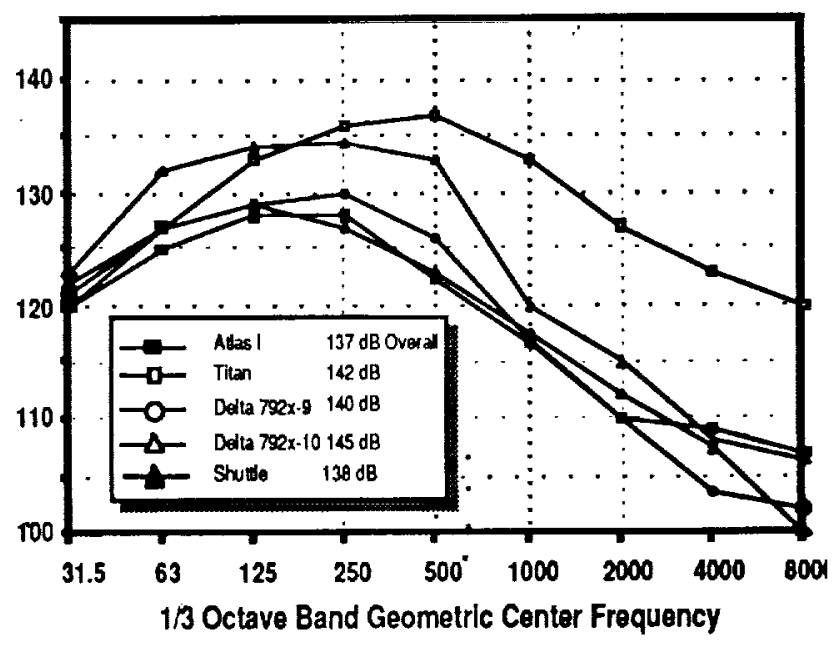


Table 1. Acceleration Environment of Payloads for Launch Systems [8]

\begin{tabular}{|c|c|c|c|c|c|c|c|c|c|}
\hline \multirow[t]{2}{*}{ Vehicle } & \multirow[t]{2}{*}{ Condition } & \multicolumn{2}{|c|}{ Lift-off } & \multicolumn{2}{|c|}{$\begin{array}{c}\text { Maximum } \\
\text { Airloads }\end{array}$} & \multicolumn{2}{|c|}{$\begin{array}{l}\text { Stage 1 } \\
\text { Shutdown } \\
\text { (Booster) }\end{array}$} & \multicolumn{2}{|c|}{$\begin{array}{l}\text { Stage 2 } \\
\text { Shutdown } \\
\text { (Booster) }\end{array}$} \\
\hline & & axial & latera & axial & |ateral & axial & lateral & axial & lateral \\
\hline \multirow{2}{*}{ T34DNUS } & steady state & +1.5 & - & +2.0 & - & +4.5 & - & +2.5 & 一 \\
\hline & dynamic & \pm 1.5 & \pm 5.0 & \pm 1.0 & \pm 2.5 & \pm 4.0 & \pm 2.0 & \pm 4.0 & \pm 2.0 \\
\hline \multirow[t]{2}{*}{ Atlas ॥ } & steady state & \pm 1.3 & - & +2.2 & +0.4 & \pm 5.5 & - & +4.0 & 一 \\
\hline & dynamic & \pm 1.5 & \pm 1.0 & \pm 0.3 & \pm 0.4 & \pm 0.5 & \pm 0.5 & \pm 2.0 & \pm 0.5 \\
\hline \multirow{2}{*}{$\begin{array}{l}\text { Della } \\
\text { Max* All } \\
\text { Series }\end{array}$} & steady state & \pm 2.4 & - & 一 & - & 一 & - & \pm 7.7 & - \\
\hline & dynamic & \pm 1.0 & \pm 2.0 & - & - & 一 & - & +4.0 & - \\
\hline \multirow[t]{2}{*}{$\mathrm{H}-\mathrm{II}$} & steady state & - & - & - & - & - & - & - & - \\
\hline & dynamic & \pm 3.2 & \pm 2.0 & - & - & 一 & 一 & \pm 5.0 & \pm 1.0 \\
\hline \multirow[t]{2}{*}{ Shuttle } & steady state & \pm 3.2 & \pm 2.5 & +1.1 & +.25 & - & - & +3.2 & +0.59 \\
\hline & dynamic & \pm 3.5 & \pm 3.4 & - & - & - & - & - & - \\
\hline
\end{tabular}

tures to approximately $200^{\circ} \mathrm{C}$ [4]

Once in orbit, the wiring will expand and contract with the orbital temperature variations. The frequency in GEO of the spacecratt passing through the Earth Shadow (see figure 3) is once per day, while in LEO this cycle occurs approximalely once every 45 minutes, depending upon orbit allitude and inclination [8]. Therefore, thermal cycling for a GEO spacecraft will not be as severe as lor a LEO spacecraft

Although the majority of satellite power systems have been $28 \mathrm{Vdc}$, systems are now planned with voltages as high as 120 Vdc. In the case of the Space Station Freedom, there will be voltages as high as $160 \mathrm{Vdc}$. Therefore, arc tracking effects at these voltages must be evaluated.

Radiation is a key issue for missions which either cross or travel within the Van Allen belts. These missions are typically either in polar orbits which cross the Van Allen belts over the Earth's poles, or highly elliplical orbits (Molniya orbits) used for communications and reconnaissance sateflites. Because charged radiation is trapped and "concentrated" in the magnetic field of the Earth, such a spacecraft receives a radiation dose significantly higher than that experienced by a GEO spacecraft .

When a spacecraft encounters a charged plasma environment, a polential may be produced between the spacecraft surfaces. When the potential voltage exceeds the breakdown threshold of the insulation, an electrostatic discharge can occur. Discharges can cause long-ferm degradation of exterior surface coatings and enhance contamination of surfaces [9].

The charged radiation trapped by the Earth's magnetic field is a product of the solar wind and consists primarily of protons and electrons and form the charged plasma regions shown in ligure 4 . The inner bell consists primarily of low energy electrons ( $20 \mathrm{keV}-1 \mathrm{Mev})$ and high energy prolons ( $\geq 600 \mathrm{MeV}$ ), and extends Irom aboul 480 $\mathrm{km}$ to $6400 \mathrm{~km}$ above the Earth. The outerbett consisting mostly of very high energy electrons ( $20 \mathrm{keV}-5 \mathrm{MeV}$ ) with lew low energy protons $(\sim 60 \mathrm{MeV})$ extends Irom $16,000 \mathrm{~km}$ to $58,000 \mathrm{~km}[9,10]$.

Iransatmosoheric Vehicles: In addition to the LEO / GEO environments, the wiring systems lor transatmospheirc vehicles experience additional environmental conditions: high humidity, vibration, temperature cycling, and fluids. For the STS, the conditions which lead to hydrolytic degradation, such as high humidity, have been eliminated by storing the orbiter in a controlled environment, and continuously purging the shuttle with conditioned air while on the launch pad [7].

The vibration to which the Irans-almospheric wiring system is exposed is intense but short-lived. The space shuttle must endure

Figure 4. Eclipse Seasons in Geosynchronous Orbit [8]

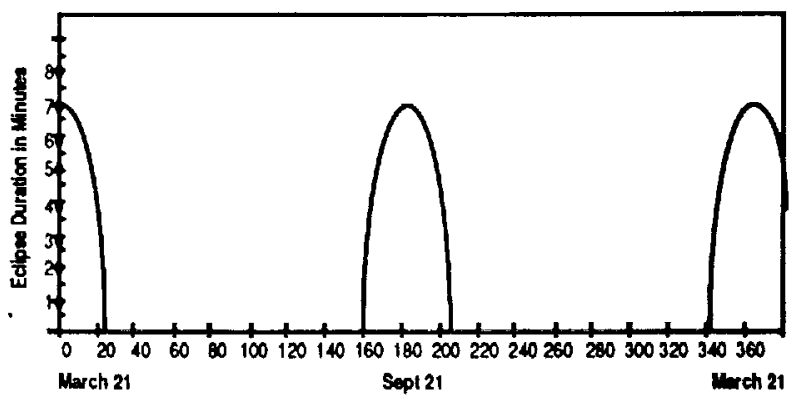


roughly 2 minutes of vibration during launch three to lour times a year. An expendable launch vehicle (ELV) must function for only one launch, therefore ELV requirements are not as sirict. All wiring must be protected from chafing against sharp edges which would damage the insulation during operational vibration or maintenance abrasion $[7,11]$

The interactions of the Irans-atmospheric wiring systems, particularly reusable launch vehicles such as the soace shuttle, with chemical and cryogenic fluids may be important. Transalmospheric vehicles experience a wide range of temperatures from cryogenic temperatures of fuels to high temperatures from rocket engines or atmospheric reentry. Cables in reusable vehicles such as the space shutthe experience a large number of temperalure cycles during their operational lifetimes which can lead to cracking, arcing, and arc-propagation.

Lunar surface: The power system for a permanently manned lunar base may have to be at a distance from the habital modules. Cables may lie exposed on the lunar surface. In general, almost all the same environmental conditions experienced in LEO / GEO will be seen by the exposed lunar base cables. In addition, problems r $\theta$ laled to temperature extremes and cycling, radiation, micromeleroids, abrasion, and lunar dust will be unique for this application. An example of a lunar base specific problem is the effect of lunar dust on initiation and propagation of an arc.

Martian Surface: Atomic oxygen in the Martian almosphere can damage cables as a result of high relative velocity impacts of the ions on the insulation, and subsequent degradation and chemical reactions. The Mars almosphere contains water vapor, however, it makes up only $0.03 \%$ of the air, and therefore, probably will not result in degradation. The Mars surface base will operate in a 95.3\% carbon dioxide and $0.13 \%$ oxygen environment. Insulation malerial musi nol react with this atmosphere [12].

A dalabase on arc tracking, wiring systems, and wiring constructions is also being established from which promising candidate insulation systems will be identified based on results of related studies. The work performed by the U.S Air Force on new wiring constructions for aerospace applications was analyzed. This database was compared to the requirements resulting from the survey. Preliminary results of this lask are depicted on lable 2.

\section{Supolemental Insulation Tests and Analysis}

The objective of this task is to provide missing information needed to evaluate potential insulation systems and to determine their suitability lor use in NASA aerospace environments. The supplemental testing and characterization efforts for the identification ol arctrackresislant aerospace wiring system are being coordinaled with the ongoing programs at other NASA and government laboratories. The database established in previous task, will be used to prioritize the enviromental and operational tesis to be performed.

Results from these tests will be combined with the results irom the database to define safe operating ranges for various insulation systems. Conditions which contribute to arc generation and propagation will be identified. The test results will be used to develop a better understanding of the life cycle of wiring insulation systems. The following are some of the preliminary tests to be performed under this effort:

Almosoheric lests: These lests concentrales on five (5) new wiring constructions (size 20 AWG, single wire) and the two (2) military standard wiring constructions. The new insulation constructions, include the Filotex, Thermatics, Nema \#3, Tensolite, and Gore configurations. The following is a list of the tests to be performed:
- Verification that the wiring construction meets the specifications.

- Full performance tests (as shown in table 3) on the Gore consiruction.

- $160 \mathrm{VDC}$ and $400 \mathrm{~Hz}, 208$ VAC dry arc resistance.

- Flammability, offgassing, and fluid compatibility.

- Cold flow resistance measurements.

Vacuum tests: Vacuum constitutes one of the stresses to which wiring systems are exposed to in the space environment. In general most insulating materials undergo some changes in their properties under such enviromental conditions. These changes, which may be prolound in polymeric dielectrics, include offgassing, brittlement and reduction in the malerial's breakdown or corona inception vollages.

Partial gravity and micro-gravity tests: Slandard vertical flammability lesis have been performed on polyimide, showing no burning. These lests, however, did not take into consideration the carbon arc tracking phenomena. Arc tracking is not a true burning mechanism that can occur in vacuum. All previous arc-tracking tests have been pertormed in a 1 gravity (g) environment. Without the heat convection process present at $1 \mathrm{~g}$, hot gasses produced by an arc in z $\mathrm{z}-$ ro-g stagnate within the vicinity raising the temperature of the insulation. This is potentially a significant problem.

Previous lests performed al 1 atmosphere may nol be relevant to an environment with lower pressure and higher oxygen concentration such as the case in a habitat module. Other effluences of interest are waste gas from the life support system and propellant from the attitude control thrusters. Ellects of these effluences on the arc tracking phenomena in zero-g will be investigated. Therefore, the effects of a zero-g environmenl, temperature, almospheric pressure, and almospheric composition on the arc lracking phenomena must be investigated.

A low cost, short duration experiment is being designed taking advantage of the in-house $\mu \mathrm{g}$ laboratory at the Lewis Research Center. Available for carrying out the partial $g$ experiments is the Lewis Research Center Lear Jet and the NASA Johnson Space Center KC-135 aircraft. These airplanes by flying in a parabolic trajectory can provide about 15 to 25 seconds of low gravity conditions. Features of the $\mu \mathrm{g}$ testing facility are described in table 4.

Results of the study phase will be used to design the experimental procedures and specifications for the fabrication/procurement of required hardware (breadboard, test subjects, support equipment and instrumentation). A database will be compiled containing the results of this battery ol experiments.

As a result ol this effort, techniques will be developed for evaluating and testing electrical wiring insulation malerials for space applications. Physical models will be developed for use by missions planners to select of competing wire insulation materials based on mission requirements.

\section{Wiring Syslems Technology}

This lask identifies issues related to safety and reliability for the complete wiring systems. Related technologies will be identified which have an impact on prevention, detection, and isolation of wiring failures and sysiem reconfiguration following a failure.

Included in the lopic of prevention techniques are evaluation techniques such as tolal quality management (TOM) which spans from 
Table 2. Air Force and NASA Mission Environmental Requirements

\begin{tabular}{|c|c|c|c|c|c|c|}
\hline $\begin{array}{l}\text { Mission } \\
\text { Pegls }\end{array}$ & Fores & $\begin{array}{l}\text { Proses } \\
\text { Modulas }\end{array}$ & $\begin{array}{l}\text { LEOI } \\
\text { GEO }\end{array}$ & $\begin{array}{l}\text { Trans } \\
\text { atmospheric }\end{array}$ & $\begin{array}{l}\text { Lunt } \\
\text { Surtace }\end{array}$ & $\begin{array}{l}\text { Mars } \\
\text { Surtece }\end{array}$ \\
\hline \multicolumn{7}{|l|}{ Electrical } \\
\hline Voltage & $\begin{array}{c}8 \mathrm{kV} \text { Impulsel } \\
1000 \mathrm{hrs} \oplus 200^{\circ} \mathrm{C} .60 \mathrm{~Hz} \\
500 \mathrm{~V} / \mathrm{s}, I_{\text {Leak }}<5 \mathrm{~mA} \\
{[3]}\end{array}$ & $\begin{array}{c}26-120 \mathrm{~V} \\
{[12\rfloor} \\
\end{array}$ & $\begin{array}{c}28-160 \mathrm{~V} \\
{[22]} \\
\end{array}$ & $\begin{array}{l}28 \cdot 270 V \\
{[14,18,23]}\end{array}$ & $\begin{array}{c}28 \cdot 160 \mathrm{~V} \\
\quad[22] \\
\end{array}$ & $\begin{array}{l}28-160 \mathrm{~V} \\
{[22]}\end{array}$ \\
\hline Frequency & $\begin{array}{l}\text { corona: dc \& } 400 \mathrm{~Hz} \\
\text { vollage withstand: } 60 \\
\mathrm{~Hz} \\
\text { arc: dc \& } 400 \mathrm{~Hz} \\
{[3]}\end{array}$ & $\begin{array}{l}d c \\
{[22]}\end{array}$ & $\begin{array}{l}d c \\
{[22]}\end{array}$ & $\begin{array}{c}d c \\
{[14,18,23]}\end{array}$ & $\begin{array}{l}\text { dc } \Rightarrow \text { ac } \\
{[22,24]}\end{array}$ & $\begin{array}{l}d c \Rightarrow \text { ac } \\
{[22.24]}\end{array}$ \\
\hline Power & $N / A$ & $\begin{array}{c}75 \mathrm{~kW} \\
{[14]} \\
\end{array}$ & $\begin{array}{c}10 ' s W \Rightarrow 10 ' s \mathrm{~kW} \\
{[22,25,26]}\end{array}$ & $\begin{array}{r}\leq 7 \mathrm{~kW} \\
{[27]} \\
\end{array}$ & $\begin{array}{r}50 \mathrm{~kW} \\
128,291 \\
\end{array}$ & $\begin{array}{r}20 \mathrm{~kW} \\
{[28,29]} \\
\end{array}$ \\
\hline \multicolumn{7}{|l|}{ Thermal } \\
\hline $\begin{array}{l}\text { Temperature/ } \\
\text { Thermal Cycling } \\
\text { (C) }\end{array}$ & $\begin{array}{c}-65 \Rightarrow 230 \\
4 \text { cycles: } 200^{\circ} \mathrm{C}, 30 \mathrm{~min} \\
-55^{\circ} \mathrm{C}, 30 \mathrm{~min} \\
{[3]}\end{array}$ & $\begin{array}{l}15 \Rightarrow 25 \\
{[13]}\end{array}$ & $\begin{array}{c}\text { LEO: }-65 \Rightarrow 120 \\
6000 / y r \\
\text { GEO: }-196 \Rightarrow 128 ; 90 / y r \\
{[4,5,16,39]}\end{array}$ & $\begin{array}{c}-200 \Rightarrow 260 \\
6000 / y r \text { in orbit } \\
{[14,16]}\end{array}$ & $\begin{array}{c}-171 \Rightarrow 111 \\
13 / y r \\
{[12]}\end{array}$ & $\begin{array}{c}-143 \Rightarrow 27 \\
356 / y r \\
{[12]} \\
\end{array}$ \\
\hline Flammability & $\begin{array}{c}\text { Afterflame } 3 \text { sec. max } \\
\text { Flame travel } 3 \text { in max } \\
{[3]}\end{array}$ & $\begin{array}{c}30 \% \text { Oxygen } \\
{[5]:} \\
\end{array}$ & N/A & $\begin{array}{c}0 \Rightarrow 30 \% \text { Oxygen } \\
{[5]:} \\
\end{array}$ & N/A & $\begin{array}{c}0.13 \% \text { Oxygen } \\
{[17]:} \\
\end{array}$ \\
\hline \multicolumn{7}{|l|}{ Mechanical } \\
\hline $\begin{array}{l}\text { Vibration/ } \\
\text { Acoustlc } \\
\text { (Abraslon) }\end{array}$ & $\begin{array}{l}\text { Unconditioned or } \\
\text { Aged } 200^{\circ} \mathrm{C} \text { for } 1000 \mathrm{hrs} \\
\text { Test: } 23^{\circ} \mathrm{C} \& 150^{\circ} \mathrm{C} \\
{[3]}\end{array}$ & $\begin{array}{c}\text { launch: } 1-10 \mathrm{~g} \\
\text { SPL: } 137-145 \mathrm{~dB} \\
{[8,13]} \\
\end{array}$ & $\begin{array}{c}\text { launch: } 1-10 \mathrm{~g} \\
\text { SPL: } 137-145 \mathrm{~dB} \\
{[8,13]}\end{array}$ & $\begin{array}{c}\text { launch: } 200 \mathrm{~g} \\
\text { SPL: } 137-145 \mathrm{~dB} \\
{[8,13,14]}\end{array}$ & $\begin{array}{c}\text { launch: } 1-10 \mathrm{~g} \\
\text { SPL: } 137-145 \mathrm{~dB} \\
{[8,13]}\end{array}$ & $\begin{array}{c}\text { launch: } 1+10 \mathrm{~g} \\
\text { SPL: } 137-145 \mathrm{~dB} \\
{[8,13]}\end{array}$ \\
\hline $\begin{array}{l}\text { Meteorolds } \\
\text { /Debris }\end{array}$ & N/A & $N / A$ & $\begin{array}{c}11-26 \text { impact } / \mathrm{m}^{3} / \mathrm{yr} \\
(\text { impacts } \geq 0.05 \mathrm{~mm}) \\
{[16]}\end{array}$ & $\begin{array}{c}0-26 \text { Impact/m } / \mathrm{m}^{3} / y r \\
\text { (impacts } \geq 0.05 \mathrm{~mm} \text { ) } \\
{[16]}\end{array}$ & 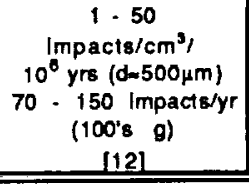 & $\begin{array}{c}\text { very low } \\
\text { probabillity } \\
{[17]}\end{array}$ \\
\hline \multicolumn{7}{|l|}{ Chemical } \\
\hline Humidity & $\begin{array}{c}15 \text { Cycles of } 6 \mathrm{hrs}, 70^{\circ} \mathrm{C} \\
995 \%, 16 \mathrm{hrs}, 38^{\prime} \mathrm{C} @ \\
95 \%: \operatorname{IR} \geq 5 \mathrm{MW} / 1000 \mathrm{ft} \\
{[3]}\end{array}$ & $\begin{array}{c}\leq 50 \% \text { inside } \\
\text { payload fairing } \\
{[13]}\end{array}$ & $\begin{array}{c}\leq 50 \% \text { inside payload } \\
\text { fairing } \\
{[13]}\end{array}$ & $\begin{array}{c}\leq 50 \% \text { in payload } \\
\text { falring } \\
\leq 100 \% \text { external } \\
{[13]}\end{array}$ & $\begin{array}{c}\leq 50 \% \text { inside payload } \\
\text { fairing } \\
{[13]}\end{array}$ & $\begin{array}{c}0.03 \% \mathrm{H}_{2} \mathrm{O} \\
100 \% \mathrm{RH} \text { at night } \\
{[12]} \\
\end{array}$ \\
\hline $\begin{array}{l}\text { Outgassing' } \\
\text { Toxicity }\end{array}$ & $\begin{array}{c}38^{\circ} \mathrm{C}, 72 \text { hrs, } 5-96 \% \text { RH, } \\
384 \text { hrs, } 200^{\circ} \mathrm{C}, 36 \text { Torr, } \\
\text { weight loss } 51.5-2 \%, \\
\text { no specific } 10 \times i c i t y \\
\text { [3] }\end{array}$ & TBD & N/A & N/A & N/A & N/A \\
\hline $\begin{array}{c}\text { Gas/Fluid } \\
\text { Compatibility }\end{array}$ & $\begin{array}{c}\text { Varlous Chemicals } \\
\text { Hydrolysis: } \\
8 \mathrm{hrs} \Phi 200^{\circ} \mathrm{C}, 672 \mathrm{hrs} \\
\text { of } 5 \% \text { salt water, } 2.5 \mathrm{kV} \text {, } \\
60 \mathrm{~Hz}, 1 \mathrm{~min} . I_{\text {Lemh }}<5 \mathrm{~mA} \\
{[3]}\end{array}$ & TBD & $\begin{array}{c}\text { AO: } 10^{7} \cdot 10^{4} \mathrm{~cm}^{-3} \\
4.3 \cdot 4.4 \mathrm{eV} \\
{[16.30]}\end{array}$ & $\begin{array}{c}\text { Water/Salt Water/ } \\
\text { Humidity/Chemicals } \\
\text { LO/LH/Hydrazine } \\
{[14,15]}\end{array}$ & $\begin{array}{c}\text { Electrostatically } \\
\text { Charged Dust } \\
\text { Particles } \\
\text { liquids TBD } \\
{[12]} \\
\end{array}$ & $\begin{array}{l}95.3 \% \mathrm{CO}_{2} \\
\text { liquids TBD } \\
{[12]} \\
\end{array}$ \\
\hline \multicolumn{7}{|c|}{ Environmental/Operational } \\
\hline Radiation & $\begin{array}{c}\text { uv: } 120 \text { cycles of } 8 \mathrm{hrs} \\
\text { uv, } 70^{\circ} \mathrm{C} .4 \mathrm{hrs} \\
\text { condensation, } 40^{\circ} \mathrm{C} \\
{[3]}\end{array}$ & $\mathbf{N} / \mathbf{A}$ & $\begin{array}{c}\text { LEO uv: } 2220 \Rightarrow 5844 \\
\text { GEO uv: } 8760 \\
\text { (ESH/yr) } \\
{[16]}\end{array}$ & $\begin{array}{c}\text { uv: } 2220 \Rightarrow 8760 \\
\mathrm{ESH} / \mathrm{yr} \\
{[16]} \\
\end{array}$ & $\begin{array}{c}\text { solar: } 1371 \mathrm{~W} / \mathrm{m}^{2} \\
\text { uv: } 8760 \mathrm{ESH} / \mathrm{yr} \\
\square 12\rfloor\end{array}$ & $\begin{array}{c}\text { Solar: } 590-650 \\
\text { W/m } \\
\text { uv: } 1656 \text { ESH/yr } \\
{[12]}\end{array}$ \\
\hline Gravity & $\begin{array}{r}1 \mathrm{~g} \\
{[3]} \\
\end{array}$ & $\begin{array}{c}10^{-6} \Rightarrow 10^{-3} 9 \\
{[18]}\end{array}$ & $\begin{array}{c}10^{6} \Rightarrow 10^{-3} \mathrm{~g} \\
{[18]}\end{array}$ & $\begin{array}{c}10^{\circ} \Rightarrow 19 \\
{[18]}\end{array}$ & $\begin{array}{c}0.165 \mathrm{~g} \\
{[12]} \\
\end{array}$ & $\begin{array}{c}0.38 g \\
{[12]} \\
\end{array}$ \\
\hline $\begin{array}{l}\text { Pressure } \\
\text { (Torr) }\end{array}$ & $\begin{array}{c}36 \Rightarrow 760 \\
{[3]}\end{array}$ & $\begin{array}{c}530 \Rightarrow 760 \\
{[5]}\end{array}$ & $\begin{array}{c}\text { LEO: } 10^{-10} \cdot 5 \times 10^{-8} \\
\text { GEO: } 7.5 \times 10^{-14} \\
{[12,19]}\end{array}$ & $\begin{array}{c}7.5 \times 10^{-14} \Rightarrow 760 \\
{[19.20]} \\
\end{array}$ & $\begin{array}{c}10^{\cdot 12} \Rightarrow 10^{\circ} \\
{[12,21]} \\
\end{array}$ & $\begin{array}{c}3 \Rightarrow 7.5 \\
{[12]}\end{array}$ \\
\hline Plasma & N/A & N/A & $\begin{array}{c}\text { LEO: } 0.3-45 \times 10^{4} \mathrm{~cm}^{.3} \\
0.1-0.2 \mathrm{eV} \\
\text { GEO: } 0.24-1.12 \mathrm{~cm}^{-3} \\
120 \cdot 295 \mathrm{keV} \\
{[5,9,19]}\end{array}$ & $\begin{array}{c}0.9 \times 10^{5} \mathrm{~cm}^{-3} \\
0.1-0.2 \mathrm{eV} \\
{[5.9 .19]} \\
\end{array}$ & $\begin{array}{c}\text { Solar Wind (H \& He) } \\
\text { Solar Galactic } \\
\text { Cosmic Rays } \\
{[12]}\end{array}$ & $\begin{array}{c}10^{3} \cdot 10^{5} \mathrm{~cm}^{-3} \\
0^{+}, a_{2}^{+}, \infty 0_{2}^{*} \\
{[12]}\end{array}$ \\
\hline $\begin{array}{l}\text { LIfetime } \\
(y / 8)\end{array}$ & $\begin{array}{l}1.7 \\
{[3]}\end{array}$ & $\begin{array}{c}30 \\
{[22]}\end{array}$ & $\begin{array}{l}\text { LEO: } 30 \\
\text { GEO: } 20 \\
{[22]}\end{array}$ & 30 & $\begin{array}{c}30 \\
{[28,29]} \\
\end{array}$ & $\begin{array}{c}30 \\
{[28,29]}\end{array}$ \\
\hline
\end{tabular}




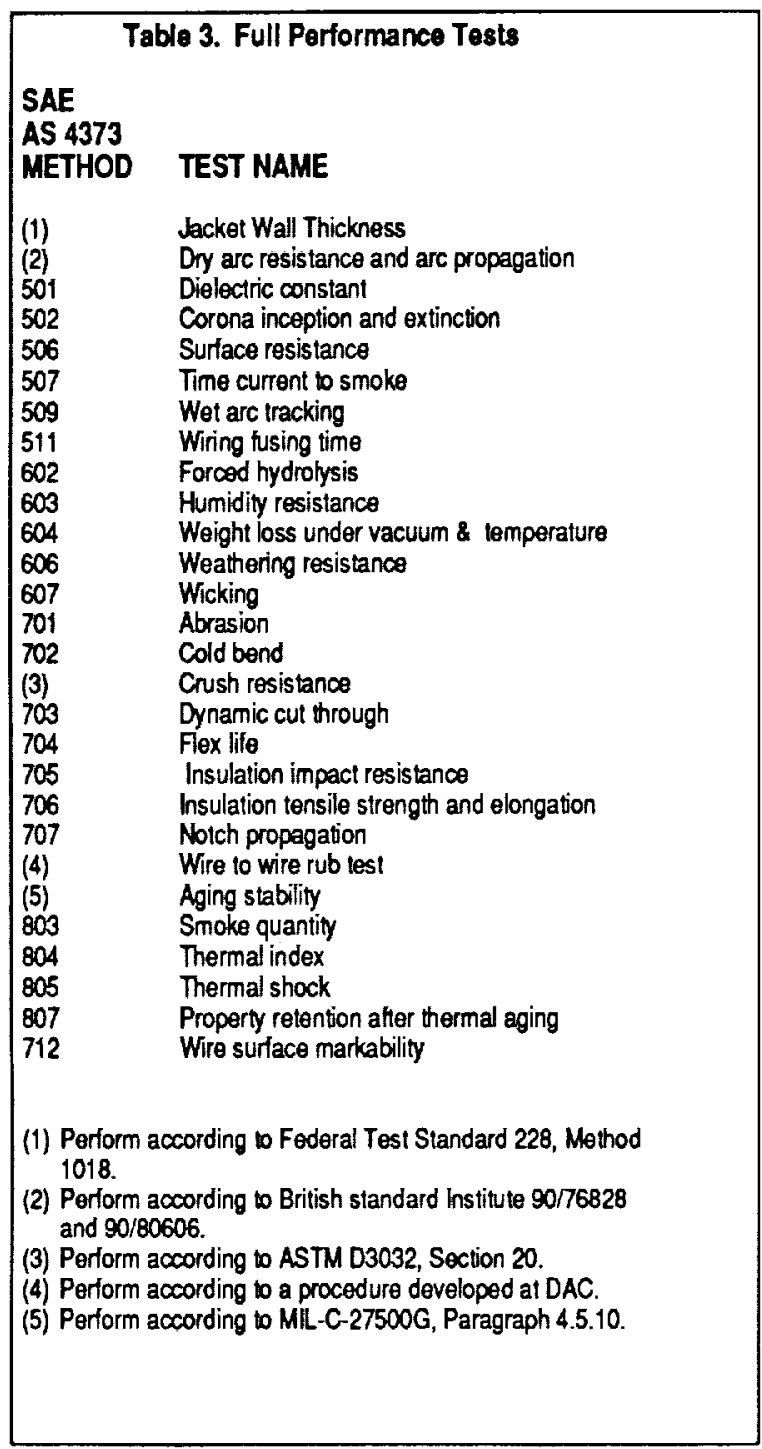

the manufacturing of the wiring to the installation and maintenance. Various approaches are being explored for circuit protection by industry. This task will identify those approaches which may be applicable to arc tracking detection and isolation. Candidate system reconfiguration techniques which may be applicable to the restoration of the system following a failure detection and isolation will also be identified.

Current practices in the manufacturing, handling, maintenance, and operational specifications for electric wiring systems in the aeronautics and space community are being studied. Particular emphasis is being given to changes in recommendations resulting from recent wiring system failures in aircraft / spacecraft. These findings will be compared to the knowledge acquired during the testing phase to determine areas requiring improvement for safety and reliability.

Methodologies will be developed and recommended which enable the verification of device and systems performance upon design completion and quality conformance to the design upon manulacture. These techniques would include in-situ techniques to verily wiring integrity. These methodologies will have to cover the entire power transmission system, i.e., wire bundles, interconnections with components, circuil protection, and integration with the mission / ve-
Table 4. $\mu g$ and partial-g testing capablity at LeRC

Features of shared facility:

- Sealed test chamber capable of vacuum to about 1.5 atms.

- Operation at quiescent or blowdown flow conditions.

- Gas handling syslem for atmospheric mixing to $30 \% \mathrm{O}_{2}$.

- Vacuum system for low pressure atmosphere and purging.

- Flow and back pressure regulation.

- Color motion-picture and video photography.

- Slandard thermocouple system and signal conditioners.

- Slandard data acquisition system and soltware.

- Provision for smoke sampling and combustion-product collection.

Specific objectives of wire-flammability tests:

- Arc tracking at low gravity.

- Ignition of adjacent luel materials.

- Off-gassing, smoke evolution, combustion products, elc

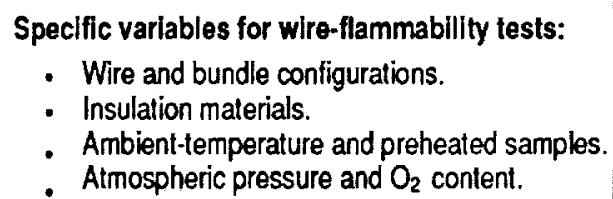

- Wire and bundle configurations.

- Insulation materials.

- Ambient-temperature and preheated samples.

- Atmospheric pressure and $\mathrm{O}_{2}$ content.

hicle structure, in order to account for synergistic elfects which may differ Irom those of separale individual wiring components.

A survey of emerging technologies and techniques will be conducted to assess polential applications of these lechnologies in the area of risk reduction and system maintainability. Those promising candidales technologies and techniques will be considered for luture development, such as: fire detection and suppression systems, sensors that could alert of impending failures in the system, and system reconfiguration schemes tollowing a failure.

\section{CONCLUSIONS}

NASA's future in manned and unmanned space activities will place increasing demands on electrical wiring and thus, increase the likelihood of an arc-induced failure. Little is known al this point of the effects of the various space environments on arc tracking phenomena.

It is anticipated that a better understanding of arc propagation in commonly used wiring insulation materials will resull from the Wiring Program for Space Applications at NASA in conjunction with the other efforts currently underway at other U.S. government laboralories, industry, and academia. 


\section{REFERENCES}

[1] Roth, T.E., "An Evaluation of the Pyrolytic and Arc-Damage Properties of polyimide Wire Insulation for Low-Voltage Applications," TR-669-001, NASA Johnson Space Cenler, White Sands Test Facility, 1991.

[2] Stueber, T.J., "Kapton Pyrolysis on Space Station Freedom's Solar Array Flexible Current Carrier". Presented at the NASA Workshop in Wiring for Aerospace Applications, NASA Lewis Research Center, Cleveland, Ohio, July 1991.

[3] Soloman, R., Woodlord, L., Domalewski, S., "New Insulation Constructions For Aerospace Wiring Applications, "WL-TR91-4066, June, 1991.

[4] Harris, R.H., "Space Station Freedom Electrical Power System Interim Primary Power Cable Insulation Study," Rockwell International Space Station Freedom Electrical Power System Cable/Connector Design, May, 1990.

[5] Hill, T.J., "Space Station Freedom Primary Power Wiring Requiremenls,"Presented al the NASA Workshop on Wiring for Aerospace Applications, NASA Lewis Research Center, Cleveland, Ohio, July, 1991.

[6] Osman, T., "Space History, " St. Martins Press, New York, 1983.

[7] Pedley, M.D., "Considerations in Using Kaplon Wire Insulation in Shuttle Systems, "NASA Johnson Space Center, August, 1988.

[8] Wertz, J.R., Larson, W.J., "Space Mission Analysis and Design," Space Technology Library, Kluwer Academic Publishers, 1991, p. 627-629.

[9] Purvis, C.K., Garrett, H.B., Whittlesey, A.C., Stevens, N.J., "Design Guidelines for Assessing and Controlling Spacecraht Charging Eflects," NASA TP-2361, September, 1984.

[10] "The Solar Array Design Handbook," The Jet Propulsion Laboratory, Pasadena, California.

[11] Van Laak, J., "polyimide Wire Concerns for Aerospace Vehicles," Presented at the NASA Workshop on Wiring lor Aerospace Applications, NASA Lewis Research Center, Cleveland, Ohio, July 23, 1991.

[12] Smith, R.E., West, G.S., "Space and Planetary Environment Criteria Guidelines for Use in Space Vehicle Development, 1982 Revision, "NASA TM 82478, January, 1983.

[13] General Dynamics Commercial Launch Services, Inc., "Mission Planners Guide for the Atlas Launch Vehicle Family," Presented al the Commercial Allas ' 89 Users Conlerence, March, 1989.

[14] McPeak, W., "Space Wiring Workshop Expendable Launch Vehicle Requirements, "Presented at the NASA Workshop on Wiring for Aerospace Applications, NASA Lewis Research Center, Cleveland, Ohio, July, 1991.

[15] Peterson, R.V., "Orbiter Kapton Wire Operational Requiremenls and Experience," Presented at the NASA Workshop on Wiring for Aerospace Applications, NASA Lewis Research Center, Cleveland, Ohio, July, 1991.
[16] Banks, B.A., Rutledge, S.K., DeGroh, K.K., Auer, B.M., Mirtich, M.J., Gebauer, L., Hill, C.M., Lebed, R.F., "LDEF Spacecraft Ground Laboratory and Computational Modeling Implications on Space Station Freedom's Solar Array Materials and Surfaces Durability," NASA Lewis Research Center, Cleveland, Ohio, 1991.

[17] Kaplan, D., "Environment of Mars, 1988," NASA TM 100470, October, 1988.

[18] "STS Investigators Guide," NASA Marshall Space Flight Center.

[19] Purvis, C.K., Ferguson, D.C., Snyder, D.B., Grier, N.T., Slaskus, J.V., Roche, J.C., "Environmenlal Interactions Considerations lor Space Station and Solar Array Design."

[20] Space Station Program Nalural Environment Definition for Design," NASA SSP 30425 Basic, January, 1991.

[21] Gaustad, K.L., Gordon, L.B., Weber, J.R., "Electrical Transmission Lines for Use on the Lunar Surlace," Presented at the NASA Workshop on Wiring for Aerospace Applications, NASA Lewis Research Center, Cleveland, Chio, July 23, 1991.

[22] "Space Station Freedom Technical Performance Measurement Report - Weight, Power, and Ram," Space Station Freedom Electrical Power System Document EID - 00375 18. August 19,1991.

[23] Nicholson, L.S., "Space Shuttle System Payload Accommodations," NSTS 07700, Volume XIV, January, 1988.

[24] Bercaw, R.W., Cull, R.C., "Future Spacecraft Power Syslems," Proceedings of the 26th Intersociety Energy Conversion Engineering Conference, Boston, Massachusetts, August, 1991.

[25] Chetty, P.R.K., "Satellite Technology and its Applications," Fairchild Space Company, Germantown, Maryland, 1991.

[26] Woosley, A.P., Smith, O.B., Nassen, H.S., "Skylab Technology Electrical Power System," Presented at the American Astronautical Society Twentieth Annual Meeting, Los Angeles, California, August 20-22, 1974.

[27] Report on the Space Shuttle Power System, NASA 8 - 78 $4162 \mathrm{C}$.

[28] NASA Report on the 90 Day Study, NASA Johnson Space Cenler, Housion TX, 1990.

[29] Pelri, D.A., Cataldo, R.L., Bozek, J.M., "Power System Requiremenls and Definition lor Lunar and Mars Outposts," Procoedings of the 25th Intersociely Energy Conversion Engineering Conference, Vol. 1, Aerospace Power Systems, Reno, Nevada, pp. 18-27, Augusi 12-17, 1990.

[30] Banks, B.A., Rutledge, S.K., "Low Earth Orbital Atomic Oxygen Simulation For Materials Durability Evaluation," Proceedings from Spacecraft Materials in Space Environment Symposium, CERT, Toulouse, France, September, 1988. 
Public reporting burden for this collection of information is estimaled to average 1 hour per response, including the time for reviewing instructions, searching existing data sources, gathering and maintaining the data needed, and completing and reviewing the collection of intormation. Send comments regarding this burden estimate or any other aspecterson collection of information, including suggestions 20r-4302, and to the Office of Management and Budget, Paperwork Reduction Project (0704-0183), Washington, DC 20503.
1. AGENCY USE ONLY (Leave blank)
2. REPORT DATE
July 1992
3. REPORT TYPE AND DATES COVERED

\section{TTTLE AND SUBTITLE}

Wiring for Acrospace Applications

6. AUTHOR(S)

J.L. Christian, Jr., J.E. Dickman, R.W. Bercaw, I.T. Myers, A.N. Hammoud, M. Stavnes, and J. Evans

\section{PERFORMING ORGANIZATION NAME(S) AND ADDRESS(ES)}

National Aeronautics and Space Administration

Lewis Research Center

Cleveland, Ohio 44135-3191

9. SPONSORING/MONITORING AGENCY NAMES(S) AND ADDRESS(ES)

National Aeronautics and Space Administration

Washington, D.C. 20546-0001
WU-323-57-4A

8. PERFORMING ORGANIZATION REPORT NUMBER

E-7204

10. SPONSORING/MONITORING AGENCY REPORT NUMBER

NASA TM-105777

11. SUPPLEMENTARY NOTES

Prepared for the 1992 Power Electronics Specialist Conference sponsored by the Institute of Elcetrical and Electronics Engineers, Toledo, Spain, June 29-July 3, 1992. J.L. Christian, Jr., J.E. Dickman, R.W. Bercaw, and I.T. Myers, NASA Lewis Rescarch Center, Cleveland, Ohio.

A.N. Hammoud and M. Stavnes, Sverdrup Technology, Inc., Lewis Research Center Group, 2001 Aerospace Parkway, Brook Park, Ohio 44142.

J. Evans, Code QE, NASA Headquarters, Washington, DC 20546. Responsible person, J.L. Christian, (216) $433-5519$.

12a. DISTRIBUTION/AVAILABILITY STATEMENT

12b. DISTRIBUTION CODE

Unclassified - Unlimited

Subject Category 33

13. ABSTRACT (Maximum 200 words)

In this paper the authors summarize the current state of knowledge of arc propagation in aerospace power wiring and efforts by the National Aeronautics and Space Administration (NASA) towards the understanding of the arc tracking phenomena in space environment. Recommendations will be made for additional testing. A database of the performance of commonly used insulating materials will be developed to support the design of advanced high power missions, such as Space Station Freedom and Lunar/Mars Exploration.

14. SUBJECT TERMS

Wiring; Arc tracking; Space power

15. MUMBER OF PAGES 8

17. SECURITY CLASSIFICATION OF REPORT

Unclassified
18. SECUAITY CLASSIFICATION OF THIS PAGE

Unclassified
9. SECURITY CLASSIFICATION OF ABSTRACT

Unclassified 